\title{
Queen and worker policing in the tree wasp Dolichovespula sylvestris
}

Received: 17 May 2004 / Revised: 27 September 2004 / Accepted: 29 November 2004 / Published online: 13 January 2005 (C) Springer-Verlag 2005

\begin{abstract}
Insect societies are sometimes exploited by workers who reproduce selfishly rather than help to rear the queen's offspring. This causes a conflict-of-interest with the mother queen and, frequently, with the non-reproductive workers as well. One mechanism that can reduce conflict is policing, whereby either the queen or other workers aggress egg-laying workers or destroy worker-laid eggs. Here we present the first direct observations of queen and worker policing in natural, unmanipulated colonies of a social insect, the tree wasp Dolichovespula sylvestris. Worker reproduction was common, with workers producing $50 \%$ of all male eggs. However, most worker-laid eggs, 91\%, were policed within 1 day, whereas most queen-laid eggs, 96\%, remained unharmed. The workers were responsible for $51 \%$ of all policing events and the queen for $49 \%$. The workers and mother queen also commonly aggressed ovipositing workers, and successfully prevented them from depositing eggs in $14 \%$ and $6 \%$ of all attempted ovipositions. Hence, both queen policing and worker policing occur and policing acts via two distinct mechanisms: selective destruction of worker-laid eggs and aggression of ovipositing workers. At a general level, our study shows that both
\end{abstract}

Communicated by R. Page

\footnotetext{
T. Wenseleers $(\bullet)$

Laboratory of Entomology, Zoological Institute, University of Leuven,

Naamsestraat 59, B-3000 Leuven, Belgium

e-mail: Tom.Wenseleers@bio.kuleuven.ac.be

Tel.: +3216323964

Fax: +32 16324575

T. Wenseleers · F. L. W. Ratnieks

Wallotstrasse 19, Berlin, 14193 Berlin, Germany

A. Tofilski · F. L. W. Ratnieks

Laboratory of Apiculture and Social Insects,

Department of Animal and Plant Sciences,

University of Sheffield,

Sheffield, S10 2TN, UK
}

Wissenschaftskolleg zu Berlin (Institute for Advanced Study), centralized and decentralized control can act together to suppress conflict within social groups.

Keywords Social policing - Reproductive conflict . Social insects · Vespinae - Dolichovespula sylvestris

\section{Introduction}

The societies of the ants, bees and wasps are often idealised. The Hutterites, for example, use the honey bee colony as an example of a harmonious, disciplined life style which can be emulated for successful and prosperous living (Hofer 1998). This common perception, however, overlooks the fact that many aspects of social insect reproduction are subject to conflict (Ratnieks and Reeve 1992; Bourke and Franks 1995). For example, colony members can be in conflict over queen rearing (nepotism, Ratnieks and Reeve 1992), male rearing (Trivers and Hare 1976; Bourke 1988; Wenseleers et al. 2004c), the sex-ratio (Bourke and Franks 1995; Crozier and Pamilo 1996; Queller and Strassmann 1998) and the caste fate of developing individuals (Bourke and Ratnieks 1999; Wenseleers et al. 2003, 2004a, 2004b; Wenseleers and Ratnieks 2004).

Conflict over male production is of particular importance in eusocial Hymenoptera. In most species, workers have lost the ability to mate and cannot, therefore, lay fertilised female-destined eggs, but do retain functional ovaries and so can lay unfertilised, male eggs (Wilson 1971). Male production is subject to a great deal of conflict, because every female, both queen and individual workers, is most related to her own sons (Trivers and Hare 1976; Wenseleers et al. 2004c). When worker reproduction occurs, it can have significant costs because reproductive workers usually perform little or no useful work in the colony (Landolt et al. 1977; Cole 1984, 1986; Moritz and Hillesheim 1985; Ross 1985; Hillesheim et al. 1989; Martin et al. 2002; Hartmann and Heinze 2003). Hence, worker reproduction can cause a "tragedy of the commons" (TOC, Hardin 1968; Wenseleers et al. 2004a; 
Table 1 Colony size and worker reproduction in eight study colonies of the tree wasp Dolichovespula sylvestris. Data are based on $16 \mathrm{~h}$ of observation (two 8-h trials) per colony

\begin{tabular}{|c|c|c|c|c|c|c|}
\hline Colony & $\begin{array}{l}\text { Year of } \\
\text { observation }\end{array}$ & $\begin{array}{l}\text { Colony size } \\
\text { (no. workers) }\end{array}$ & $\begin{array}{l}\text { No. queen } \\
\text { ovipositions } \\
\text { (per h) }\end{array}$ & $\begin{array}{l}\text { No. succesful } \\
\text { ovipositions by all } \\
\text { workers (per h) }\end{array}$ & $\begin{array}{l}\% \text { Eggs } \\
\text { worker laid }\end{array}$ & $\begin{array}{l}\text { Estimated \% } \\
\text { of male eggs } \\
\text { worker laid }^{\mathrm{a}}\end{array}$ \\
\hline 1 & 2003 & 37 & $36(2.3)$ & $9(0.6)$ & $20.0 \%$ & $40.0 \%$ \\
\hline 2 & 2004 & 60 & $21(1.3)$ & $0(0.0)$ & $0.0 \%$ & $0.0 \%$ \\
\hline 3 & 2004 & 63 & $20(1.3)$ & $2(0.1)$ & $9.1 \%$ & $21.1 \%$ \\
\hline 4 & 2004 & 75 & $40(2.5)$ & $18(1.1)$ & $31.0 \%$ & $55.0 \%$ \\
\hline 5 & 2003 & 107 & $24(1.5)$ & $14(0.9)$ & $36.8 \%$ & $60.9 \%$ \\
\hline 6 & 2003 & 143 & $36(2.3)$ & $67(4.2)$ & $65.1 \%$ & $83.2 \%$ \\
\hline 7 & 2004 & 160 & $38(2.4)$ & $12(0.8)$ & $24.0 \%$ & $45.7 \%$ \\
\hline 8 & 2003 & 184 & $7(0.4)$ & $115(7.2)$ & $94.3 \%$ & $97.8 \%$ \\
\hline Total/mean & & 104 & $222(1.7)$ & 237 (1.9) & $35.0 \%$ & $50.4 \%$ \\
\hline 95\% C.L. ${ }^{\mathrm{b}}$ & & & & & {$[17.0-56.0 \%]$} & {$[30.0-71.0 \%]$} \\
\hline
\end{tabular}

${ }^{\mathrm{a}}$ Calculated given that the queen lays 37.5\% male eggs, since large cells contain 60\% queens and 40\% males (Archer 2002), and 10\% of the adult males are worker produced (Foster et al. 2001)

${ }^{\mathrm{b}}$ Calculated as the 2.5 th and 97.5 th percentiles of a simulated probability distribution obtained by bootstrapping over colonies $(n=10,000$ iterations)

Wenseleers and Ratnieks 2004), with individual selfish interests (worker reproduction) potentially leading to a group cost (reduced foraging and lowered colony productivity).

Theory has shown that conflict over male parentage can be resolved through policing, whereby the queen or non-reproductive workers prevent worker reproduction by aggressing reproductive workers or destroying workerlaid eggs (Trivers and Hare 1976; Starr 1984; Ratnieks 1988). In relatedness terms, the queen is selected to carry out such policing because she is always more closely related to own sons $(r=1 / 2)$ than to worker's sons, grandsons ( $r=1 / 4$, Trivers and Hare 1976). The workers are selected to police, on relatedness grounds alone, at paternity frequencies greater than 2 , because workers are then on average more closely related to queen's sons, brothers $(r=0.25)$, than to other worker's sons (full- and half-nephews, $r<0.25$ ) (Starr 1984; Woyciechowski and Lomnicki 1987; Ratnieks 1988). However, worker policing can also be favoured, even when queens are mated to fewer than two males, if policing increases colony efficiency (Ratnieks 1988) or if it allows the workers to bias the sex ratio towards females (the worker optimum, Trivers and Hare 1976) by the low-cost killing of males at the egg stage (Foster and Ratnieks 2001b).

Empirically, worker policing was first discovered in the honey bee Apis mellifera (Ratnieks and Visscher 1989), and later in several other species of honeybees, ants and Vespinae wasps (reviewed by Ratnieks 2000; Barron et al. 2001; Foster and Ratnieks 2001c; Wenseleers et al. 2004a, 2004c; Ratnieks and Wenseleers 2005). One shortcoming, however, in the empirical demonstration of worker policing is that most studies have relied on experimental manipulations in which egg-laying workers or worker-laid eggs from a queenless colony are introduced into a queenright discriminator colony (e.g. Ratnieks and Visscher 1989; Gobin et al. 1999; Kikuta and Tsuji 1999; D'Ettorre et al. 2004). Only in A. mellifera have data been obtained from natural colonies (Ratnieks 1993; Visscher 1996), but these studies merely tracked cohorts of eggs, and did not observe actual worker egg laying and egg killing (Ratnieks 1993; Visscher 1996). Queen policing, in turn, has been shown conclusively in only one species, the ant Dinoponera quadriceps (Monnin and Peeters 1997), and is otherwise only known from anecdotal reports (e.g. Free et al. 1969; Pomeroy 1979; Greene 1979; Michener and Brothers 1974) or manipulations similar to those used to demonstrate worker policing (Diacamma sp.: Kikuta and Tsuji 1999). Hence, it is valuable to obtain more data on policing measured in a natural context.

The aim of this study is to present the first detailed, quantitative study of queen and worker policing in natural, unmanipulated colonies of a social insect-the tree wasp Dolichovespula sylvestris. Our results show that worker reproduction is common, but that it is prevented from being successful through a combination of queen and worker policing. Policing is shown to occur via two distinct mechanisms, the selective destruction of worker eggs and the aggressive interference with ovipositing workers. At a general level, our study shows that both centralized and decentralized control can act together to suppress conflict within social groups.

\section{Methods}

Study organism

Forty-five nests of the tree wasp $D$. sylvestris were collected in the Sheffield area, UK in June 2003 and 2004. Colonies have a short annual cycle, with nests typically being founded in spring by a single overwintered and inseminated queen and dying out in JulyAugust after the production of young males and queens (Edwards 1980). Nests consist of 1-5 parallel horizontal combs, surrounded by multiple layers of nest envelope. All colonies were nesting in bird boxes and came from pest control calls following an article in the local newspaper. Ten queenless nests and five nests that were near the end of their life cycle were not used. The remaining 30 nests were transferred into observation nest boxes at the Laboratory of Apiculture and Social Insects, University of Sheffield. Out of these, eight thriving, healthy looking nests were used for observation (Table 1). 
Nest boxes

Observation boxes were made from 13-mm plywood and were 15 (width) $\times 17$ (depth) $\times 20$ (height) $\mathrm{cm}$ externally with a 4-cm diameter circular entrance hole. Boxes were fixed to the outside wall of the laboratory building $3 \mathrm{~m}$ above ground. The bottom was hinged to allow a video camera to be inserted for observation (see below). During relocation, the queen was marked with a white bee tag (Opilathplättchen) and the combs, with the marked queen and the workers, were placed on horizontal wires inside the nest box. The colony was then provided with honey to help it recover. On the morning of the next day, the entrance was opened and the workers were allowed to fly.

\section{Observation of worker egg laying and policing}

All colonies were observed using a small infrared night vision camera mounted in a $3.0 \times 2.0 \times 1.5$-in clear perspex box (Maplin, model MS37S), which was placed at the bottom of each next box and connected to a computer using an AVerMedia EZMaker framegrabber and VirtualDub (http://www.virtualdub.org/) software. This allowed time-lapse ( 5 frames/s) digital video recording onto the computers' hard disk. Observations began at the start of the reproductive phase of the colony life cycle, in the middle of June, when the nests contained an upper comb of small cells, for rearing workers, and a small lower comb of large cells, for rearing males and queens. Colony size, at the time of observation, ranged from 37 to 184 workers (mean $104 \pm 53$ SD; Table 1). To determine egg maternity and to follow the fate of any eggs that were laid we removed the lower part of the nest envelope, glued the lower sexual comb onto a piece of thin wire and removed any eggs or larvae that were in it so that all cells were available for egg laying. The comb was then put back into its original position using children's modelling clay to hold the wire. Subsequently, we observed queen and worker egg laying for $8 \mathrm{~h}$ per trial, and checked the comb by eye once per hour to look for the appearance of new eggs or the absence of eggs laid earlier. The positions of all eggs were recorded onto a map of the comb, which allowed us to determine cases in which an egg had been replaced by a new egg laid in another position inside the cell between the hourly checks. All video recordings were then analysed in detail to determine how many were queen-laid eggs and worker-laid eggs, and how many eggs were policed by either the queen or the workers. One final check of the comb was made $16 \mathrm{~h}$ after the start of the trial, allowing the fate of all eggs to be followed for nearly 1 day. This whole procedure was replicated twice for each colony, and the data was pooled.

Egg laying is conspicuous, as it involves a worker or the queen inserting her abdomen into a cell (mean duration: workers $1.65 \min \pm 0.36 \mathrm{SD}, n=28$; queens $2.0 \min \pm 0.36 \mathrm{SD}, n=28)$. Egg policing is also clearly observable since it involves the prolonged insertion of the head inside a cell (mean duration: 43.0 s $\pm 21.5 \mathrm{SD}$, $n=26$ for queen policing and $39.1 \mathrm{~s} \pm 22.4 \mathrm{SD}, n=54$ for worker policing), followed by rotating or upward and downward movements, which clearly indicate that the egg inside is being eaten. Empty cells never received such prolonged visits. Policing events could be easily distinguished from routine cell visits, as these lasted for an average of only $3.0 \mathrm{~s}$ (mean duration: $3.7 \mathrm{~s} \pm 2.9 \mathrm{SD}, n=40$ for queen and $2.4 \mathrm{~s} \pm 1.9 \mathrm{SD}, n=40$ for workers) and usually did not involve deep insertion of the head into the cell as with egg eating. (Feeding larvae does require this, but feeding did not occur since study combs contained only eggs.) The hourly checks of the combs confirmed the correct interpretation of all egg-eating events. In addition, to document queen-worker and worker-worker conflict over male parentage, we also noted any queen-worker or workerworker aggression during oviposition.

\section{Statistical analysis}

Survivor functions of queen-laid and worker-laid eggs were determined using the Kaplan-Meier product-limit method (Lee and
Wang 2003) as implemented in Statistica 6 (Statsoft 1995), which takes into account the censored nature of the data. That is, the fate of eggs laid near the end of the trial could not be followed for as long as for the eggs laid at the beginning of the trial. The average survival of queen-laid and worker-laid eggs was compared using Gehan's Wilcoxon test (Lee and Wang 2003). One-way Fisher's exact tests (Siegel and Castellan 1988) were used to determine whether worker-laid eggs were selectively eaten by the queen or the workers.

\section{Results}

Egg laying by queen and workers

Worker reproduction was found to be common in seven out of eight study colonies, with 9-94\% of all eggs being worker laid; in one colony no worker reproduction could be detected (Table 1). Overall, 35\% of all eggs were worker laid (95\% C.L.: $17-56 \%$, Table 1). Given that in D. sylvestris, the queen lays $37.5 \%$ male eggs (Table 1), this means that on average $50 \%$ of all male eggs were worker laid (95\% C.L.: 30-71\%, Table 1). The proportion of worker-laid male eggs is significantly positively correlated with colony size $(\gamma=0.64, Z=2.23, P=0.03)$. Such a correlation is expected when reproductive workers make up a fixed percentage of the whole colony (Wenseleers et al. 2004c), since large colonies would then contain a greater number of egg-laying workers.

The egg-laying rate of the queen varied from 0.4 to 2.5 eggs $/ \mathrm{h}$ (mean $=1.7 / \mathrm{h} \pm 0.72 \mathrm{SD}, n=8$ colonies, 222 ovipositions) and that of the workers collectively (when worker reproduction occurred) from 0.1 to $7.2 \mathrm{eggs} / \mathrm{h}$ (overall mean $=1.9 / \mathrm{h} \pm 2.5 \mathrm{SD}, n=8$ colonies, 237 ovipositions). Although we could not determine how many workers were laying eggs at the time of our observations, Foster et al. (2001) estimated that $D$. sylvestris colonies contain an average of five laying workers. This would mean that a single laying worker deposits approximately one egg every $2.6 \mathrm{~h}$, and that individual workers are approximately 4.5 times less fecund than queens.

\section{Policing of worker egg laying}

Worker oviposition was sometimes associated with aggression (Table 2). In 54/299 (18.1\%) and 25/299 (8.4\%) of all attempted worker ovipositions, another worker or the mother queen, respectively, grasped the egg-laying worker and tried to sting her or push her off the cell. In $43 / 299=14.4 \%$ and $19 / 299=6.4 \%$ of all attempted ovipositions, aggression successfully prevented egg laying (Table 2). This was evident from the fact that the ovipositing worker immediately retracted her abdomen from the cell and that no egg was ever found inside these cells at subsequent checks of the combs (Table 2). Although it was generally unknown whether the aggressing workers were laying or nonlaying workers, in five cases, four times in colony 8 and once in colony 6 , the aggressing worker had been seen to lay an egg just before. 
Table 2 Number of worker ovipositions that were disrupted as a result of aggression by the mother queen or other workers

\begin{tabular}{|c|c|c|c|c|c|}
\hline \multirow[t]{3}{*}{ Colony } & \multirow{3}{*}{$\begin{array}{l}\text { Total number } \\
\text { of attempted worker } \\
\text { ovipositions } \\
\text { (observation time: } \\
16 \mathrm{~h} \text { ) }\end{array}$} & \multicolumn{4}{|c|}{ Number of worker ovipositions associated with: } \\
\hline & & \multicolumn{2}{|c|}{ Aggression by workers } & \multicolumn{2}{|c|}{ Aggression by the queen } \\
\hline & & $\begin{array}{l}\text { Oviposition } \\
\text { continued (\%) }\end{array}$ & $\begin{array}{l}\text { Oviposition } \\
\text { broken off }^{\mathrm{a}}(\%)\end{array}$ & $\begin{array}{l}\text { Oviposition } \\
\text { continued (\%) }\end{array}$ & $\begin{array}{l}\text { Ovipositions } \\
\text { broken off }{ }^{\mathrm{a}}(\%)\end{array}$ \\
\hline 1 & 9 & $0(0 \%)$ & $0(0 \%)$ & $2(22.2 \%)$ & $0(0 \%)$ \\
\hline 2 & 0 & $0(0 \%)$ & $0(0 \%)$ & $0(0 \%)$ & $0(0 \%)$ \\
\hline 3 & 3 & $2(66.7 \%)$ & $0(0 \%)$ & $0(0 \%)$ & $1(33.3 \%)$ \\
\hline 4 & 35 & $0(0 \%)$ & $1(2.9 \%)$ & $2(5.7 \%)$ & $16(45.7 \%)$ \\
\hline 5 & 14 & $0(0 \%)$ & $0(0 \%)$ & $0(0 \%)$ & $0(0 \%)$ \\
\hline 6 & 88 & $5(5.7 \%)$ & $20(22.7 \%)$ & $1(1.1 \%)$ & $1(1.1 \%)$ \\
\hline 7 & 12 & $0(0 \%)$ & $0(0 \%)$ & $0(0 \%)$ & $0(0 \%)$ \\
\hline 8 & 138 & $4(2.9 \%)$ & $22(16.0 \%)$ & $1(0.7 \%)$ & $1(0.7 \%)$ \\
\hline Total/mean & 299 & $11(3.7 \%)$ & $43(14.4 \%)$ & $6(2.0 \%)$ & $19(6.4 \%)$ \\
\hline
\end{tabular}

a Oviposition was broken off prematurely as evidenced by the immediate retraction of the worker's abdomen from cell; no egg could ever be found inside these cells at subsequent checks of the combs

This implies that the observed aggression may be driven, at least in part, by competition for egg-laying opportunities. Workers were never seen to prevent the queen from laying eggs.

In the eight colonies combined, we also observed 127 and 16 cases of worker-worker and queen-worker aggression not associated with egg laying, in which a worker was grasped and an attempt was made to bite or sting her. In one case, in colony 8 , the aggressing worker was an egg-laying worker, as it had laid an egg just before, but whether the aggressed workers were also egglaying workers could not be confirmed.

\section{Policing of worker-laid eggs}

Most of the worker-laid eggs, 91\%, were removed within $16 \mathrm{~h}$, whereas most of the queen-laid eggs, 96\%, were unharmed (Table 3, Fig. 1). Both the queen and the workers carry out policing. Across all colonies, the workers were responsible for $49 \%$ of all eggs killed and the queen for $51 \%$ (Table 3). Both queen and worker policing were characterised by accurate discrimination against worker-laid eggs (Table 3; overall significance, $P<0.0001)$. For each colony, the combined action of queen and worker policing resulted in the removal of significantly more worker-laid than queen-laid eggs (Table $3 ; P<0.0001)$. In colony 5 , queen policing was not observed. However, since the majority of the policing in this colony occurred overnight the identity of most of the policing individuals could not be determined.

The overall effect of the policing was that worker-laid eggs had a much lower survival than queen-laid eggs (Fig. 1; Gehan's Wilcoxon test, $P<0.0001$ ): half of all worker-laid eggs were removed within $40 \mathrm{~min}$ after egg laying, while $96 \%$ of all queen eggs were still pres-ent $16 \mathrm{~h}$ after the start of the experiment (Fig. 1). Interestingly, the survival curve of worker eggs was significantly different from a simple exponential decline: $\left(X_{2}^{2}=115.43, P<1.10^{-10}\right)$, and instead followed a Gompertz survival model in which the mortality rate declines exponentially as time progresses (this model did not deviate significantly from the observed survival curve: $\left.X_{1}^{2}=0.60, P<0.44\right)$. The policing rate of workerlaid eggs that were $2 \mathrm{~h}$ old was $58.2 \%$ per $2 \mathrm{~h}$ and this dropped to $16.3 \%$ and $4.4 \%$ for eggs that were $2-4 \mathrm{~h}$ and 4-6 h old.

\section{Discussion}

Our data show that levels of worker reproduction are unusually high in the tree wasp D. sylvestris: $50 \%$ of all male eggs were worker laid (Table 1). Similarly high levels of worker reproduction in social insects have previously only been shown in one other Dolichovespula, $D$. saxonica (Foster and Ratnieks 2000) and in some stingless bees (Tóth et al. 2002, 2004). However, both the workers and the queen policed worker-laid eggs and aggressed ovipositing workers, thereby limiting successful worker reproduction (Fig. 1, Tables 2, 3). Interestingly, the queen was never aggressed by the workers, and the workers almost never ate queen-laid eggs, presumably because many of these would be female, and there would be a large cost of killing sisters. The net result was that the queen's reproduction was greatly favoured, at the expense of worker reproduction. This explains why only $10 \%$ of all adult males are worker produced in D. sylvestris (Foster et al. 2001).

Importantly, our policing assays used naturally occurring egg-laying workers and worker-laid eggs, unlike previous studies which have mostly relied on the introduction of eggs or workers from queenless colonies (e.g. Ratnieks and Visscher 1989; Gobin et al. 1999; Kikuta and Tsuji 1999; D'Ettorre et al. 2004). This allowed accurate determination of natural policing rates, thereby filling an important gap in the literature. The policing rate of worker-laid eggs was found to be age dependent, with older eggs having greater survival than newly laid ones (Fig. 1). This indicates that older eggs have a lesser 
Table 3 Proportions of worker-laid eggs policed within $8 \mathrm{~h}$ and $16 \mathrm{~h}$ of the start of each trial and the percentage of all egg policing that was by the queen versus by workers. The selectivity of the policing was tested using one-way Fisher's exact tests

\begin{tabular}{|c|c|c|c|c|c|c|c|}
\hline \multirow[t]{2}{*}{ Colony } & \multirow[t]{2}{*}{$\begin{array}{l}\text { Initial } \\
\text { situation } \\
\text { (no. eggs) }\end{array}$} & \multicolumn{2}{|c|}{ Eggs policed within } & \multirow{2}{*}{$\begin{array}{l}\% \text { of all } \\
\text { policing that } \\
\text { was by the } \\
\text { queen vs by } \\
\text { workers }\end{array}$} & \multicolumn{3}{|c|}{$\begin{array}{l}\text { Significance of policing in terms } \\
\text { of discrimination against worker-laid } \\
\text { eggs by: }\end{array}$} \\
\hline & & $8 \mathrm{~h}(\%)$ & $16 \mathrm{~h}(\%)$ & & Queen & Workers & Overall \\
\hline \multicolumn{8}{|l|}{1} \\
\hline Queen-laid eggs & 36 & $2(5.6 \%)$ & $7(19.4 \%)$ & & & & \\
\hline $\begin{array}{l}\text { Worker-laid eggs } \\
2\end{array}$ & 9 & $5(55.6 \%)$ & $8(88.9 \%)$ & $60.0 \%$ & 0.003 & NS & 0.0002 \\
\hline Queen-laid eggs & 21 & $0(0.0 \%)$ & $0(0.0 \%)$ & & & & \\
\hline $\begin{array}{l}\text { Worker-laid eggs } \\
3\end{array}$ & 0 & $0(0.0 \%)$ & $0(0.0 \%)$ & & & & \\
\hline Queen-laid eggs & 20 & $0(0.0 \%)$ & $0(0.0 \%)$ & & & & \\
\hline $\begin{array}{l}\text { Worker-laid eggs } \\
4\end{array}$ & 2 & $2(100.0 \%)$ & $2(100.0 \%)$ & $100.0 \%$ & 0.004 & & 0.004 \\
\hline Queen-laid eggs & 40 & $0(0.0 \%)$ & $0(0.0 \%)$ & & & & \\
\hline $\begin{array}{l}\text { Worker-laid eggs } \\
5\end{array}$ & 18 & $14(77.8 \%)$ & $17(94.4 \%)$ & $92.9 \%$ & $1.10^{-9}$ & NS & $9.10^{-14}$ \\
\hline Queen-laid eggs & 24 & $0(0.0 \%)$ & $0(0.0 \%)$ & & & & \\
\hline $\begin{array}{l}\text { Worker-laid eggs } \\
6\end{array}$ & 14 & $5(35.7 \%)$ & $10(71.4 \%)$ & $0.0 \%$ & & 0.02 & $2.10^{-6}$ \\
\hline Queen-laid eggs & 36 & $1(2.8 \%)$ & $2(5.6 \%)$ & & & & \\
\hline Worker-laid eggs & 67 & $41(61.2 \%)$ & $55(82.1 \%)$ & $9.7 \%^{\mathrm{b}}$ & NS & $2.10^{-7}$ & $9.10^{-15}$ \\
\hline Queen-laid eggs & 38 & $0(0.0 \%)$ & $0(0.0 \%)$ & & & & \\
\hline $\begin{array}{l}\text { Worker-laid eggs } \\
8\end{array}$ & 12 & $10(83.3 \%)$ & $10(83.3 \%)$ & $60.0 \%$ & $3.10^{-6}$ & $1.10^{-4}$ & $6.10^{-9}$ \\
\hline Queen-laid eggs & 7 & $0(0.0 \%)$ & $0(0.0 \%)$ & & & & \\
\hline $\begin{array}{l}\text { Worker-laid eggs } \\
\text { Totoal or mean }\end{array}$ & 115 & $107(93.0 \%)$ & $113(98.3 \%)$ & $22.7 \%^{\mathrm{b}}$ & 0.0009 & $2.10^{-6}$ & $6.10^{-10}$ \\
\hline Queen-laid eggs & 222 & $3(1.4 \%)$ & $9(4.1 \%)$ & & & & \\
\hline Worker-laid eggs & 237 & $184(77.6 \%)$ & $215(90.7 \%)$ & $30.3 \%$ & $2.10^{-28}$ & $4.10^{-50}$ & $4.10^{-91}$ \\
\hline & & Weighting col & s equally & $49.3 \%[22.5$ & $6.1 \%$ ] 95 & c & \\
\hline
\end{tabular}

${ }^{\mathrm{a}}$ Based on the policing of worker-laid eggs within the first $8 \mathrm{~h}$ of each trial. The three queen-laid eggs that were removed in colonies 1 and 6 were policed by workers

${ }^{\mathrm{b}}$ For 10/38 (colony 6) and 19/86 (colony 8) policing events it could not be determined unambiguously whether the queen or the workers ate the egg as both made cell visits in the time interval in which the egg was policed; these policing events are not included in the estimated percentage of the policing that was by the queen versus by workers

${ }^{\mathrm{c}}$ Calculated as the 2.5 th and 97.5 th percentiles of a simulated probability distribution obtained by bootstrapping over colonies $(n=10,000$ iterations)

chance of being policed, or that the worker-laid eggs that remain are those that are inherently more acceptable, for instance being more queen-like in their smell (cf. Ratnieks 1995). A similar reduction in the policing rate of worker-laid eggs over time has been observed in the honeybee (Ratnieks 1993).

The occurrence of queen policing is expected given that $D$. sylvestris has small colonies (Table 1, Foster et al. 2001), which is suggested to be a requirement for centralized queen control to be effective (Ratnieks 1988; Bourke 1999). Indeed, queen policing has so far only been found in small-colony species, including the ants Dinoponera quadriceps (Monnin and Peeters 1997) and Diacamma sp. (Nakata and Tsuji 1996; Kikuta and Tsuji 1999), bumblebees (Free et al. 1969; Pomeroy 1979; Cnaani et al. 2002) and perhaps also other Dolichovespula (Greene 1979; Foster and Ratnieks 2001c), Polistes (Fletcher and Ross 1985; Spradbery 1991; Saigo and Tsuchida 2002) and Lasioglossum (Michener and Brothers 1974). By contrast, centralized queen control would be impossible, and indeed does not occur, in species with much larger colonies, such as the common wasp Vespula vulgaris (Foster and Ratnieks 2001a) and Apis honeybees (Barron et al. 2001; Halling et al. 2001), which have colonies of up to 3,000 and 50,000 workers (Winston 1987; Foster and Ratnieks 2001a; Foster et al. 2002).

The occurrence of worker policing in D. sylvestris is more surprising. Foster and Ratnieks (2000) showed that colonies of $D$. saxonica headed by a multiply mated queen produce relatively fewer worker-derived males than colonies headed by a singly mated queen (Ratnieks 1988). This was interpreted as worker policing occurring only in multiple paternity colonies, in line with policing theory (Ratnieks 1988). In D. sylvestris, however, queens are primarily singly mated (mean effective paternity $=1.15$ ), and sister-sister relatedness is high, 0.68 (Foster et al. 2001). As a result, worker policing should not have relatedness benefits, since the average relatedness to workers' sons exceeds the relatedness to queen's sons. Nevertheless, it is possible that worker policing has other selective benefits in this species, such as improving colony efficiency (Ratnieks 1988), or bringing the sex ratio 


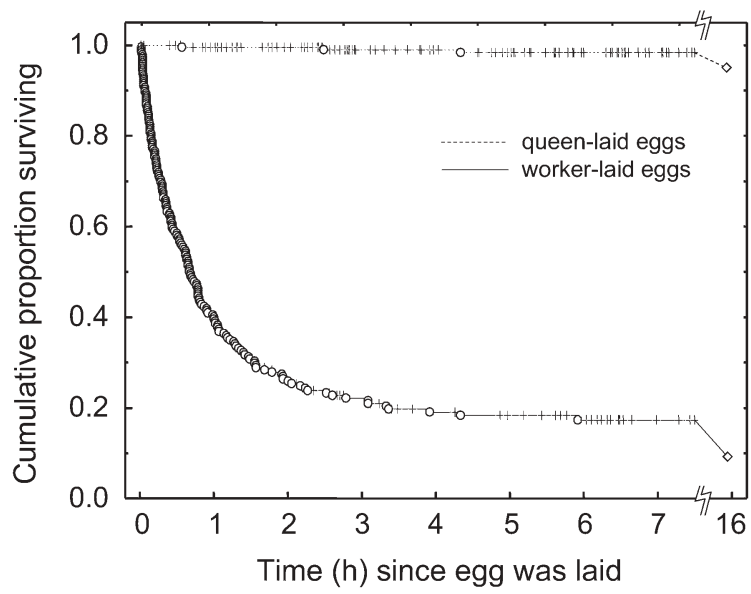

Fig. 1 Survival of queen-laid $(n=222)$ and worker-laid $(n=237)$ eggs in queenright Dolichovespula sylvestris colonies (KaplanMeier analysis) since being laid. Half the worker-laid eggs were policed within $40 \mathrm{~min}$ of being laid, whereas most, $96 \%$, of the queen-laid eggs remained for at least $16 \mathrm{~h}$. This difference in survival is highly significant (Gehan's Wilcoxon test, $P<0.000001$ ). Data are pooled across a total of 16 trials performed using 8 colonies. Open circles and crosses are complete and censored observations, respectively

closer to the worker optimum (Foster and Ratnieks 2001b). An additional possibility is that worker policing in D. sylvestris primarily reflects worker-worker competition for egg-laying opportunities. Our data suggest that this may be the case since five workers who aggressed egg-laying workers were themselves laying eggs. In Vespinae wasps in which brood are reared in cells, and in which there are few vacant cells, killing an egg makes a cell more suitable for laying into. Worker policing would then have purely selfish benefits, as it would result in the rearing of more sons, and this would be selected for under any paternity as each worker is more related to own sons than to other worker's sons (nephews). Further work is needed to test this hypothesis and demonstrate whether worker policing in D. sylvestris is driven by direct reproduction motives. If true, however, it would be important as it would constitute an entirely novel form of social insect policing, which could be termed "corrupt worker policing", by analogy to human policing where corruption refers to the abuse of police authority for personal gain.

Overall, our study provides a particularly clear picture of queen-worker conflict over male parentage in a social insect, and of the policing mechanisms that help to resolve it. "Despotic" queen control was surprisingly important in the prevention of successful worker reproduction, particularly considering that the single queen has to dominate a whole society containing a hundred or more workers-a possibility that some had previously dismissed as unfeasible (Hammond and Keller 2004). On the other hand, "decentralised" worker policing through egg eating and aggression was about equally important in suppressing worker reproduction. In vertebrate societies or family groups, individual selfishness can also be po- liced or punished (Clutton-Brock and Parker 1995; Mock and Parker 1998), and the way in which this is achieved may also be through a combination of centralised and decentralised control mechanisms. Typically, however, one of both systems always plays the upper hand. For example, sibling rivalry would typically be resolved through centralised parental control (Mock and Parker 1998), whereas humans resolve conflicts mostly through the deployment of a decentralised police force. Tree wasp colonies are unusual in that both mechanisms occur alongside each other, making them neither democratic nor truly despotic.

Acknowledgements This work was supported by the 'Insects' TMR network and an E.C. Marie Curie Fellowship to T.W. We thank Luke Holman and Fabio S. Nascimento for help with data collection.

\section{References}

Archer ME (2002) A numerical account of the development of colonies of the social wasp, Dolichovespula sylvestris (Scopoli) (Hym., Vespinae), in England and overseas. Entomol Mon Mag 138:209-224

Barron AB, Oldroyd BP, Ratnieks FLW (2001) Worker reproduction in honey-bees (Apis) and the anarchic syndrome: a review. Behav Ecol Sociobiol 50:199-208

Bourke AFG (1988) Worker reproduction in the higher eusocial Hymenoptera. Q Rev Biol 63:291-311

Bourke AFG (1999) Colony size, social complexity and reproductive conflict in social insects. J Evol Biol 12:245-257

Bourke AFG, Franks NR (1995) Social evolution in ants. Princeton University Press, Princeton, N.J.

Bourke AFG, Ratnieks FLW (1999) Kin conflict over caste determination in social Hymenoptera. Behav Ecol Sociobiol 46:287297

Clutton-Brock TH, Parker GA (1995) Punishment in animal societies. Nature 373:209-216

Cnaani J, Schmid-Hempel R, Schmidt JO (2002) Colony development, larval development and worker reproduction in Bombus impatiens Cresson. Insectes Soc 49:164-170

Cole BJ (1984) Colony efficiency and the reproductivity effect in Leptothorax allardycei (Mann). Insectes Soc 31:403-407

Cole BJ (1986) The social behavior of Leptothorax allardycei (Hymenoptera, formicidae): time budgets and the evolution of worker reproduction. Behav Ecol Sociobiol 18:165-173

Crozier RH, Pamilo P (1996) Evolution of social insect colonies. Sex allocation and kin selection. Oxford University Press, Oxford

D'Ettorre P, Heinze J, Ratnieks FLW (2004) Worker policing by egg-eating in the ponerine ant Pachycondyla inversa. Proc $\mathrm{R}$ Soc Lond Ser B Biol Sci 271:1427-1434

Edwards R (1980) Social wasps: their biology and control. Rentokil, East Grinstead

Fletcher DJC, Ross KG (1985) Regulation of reproduction in eusocial Hymenoptera. Annu Rev Entomol 30:319-343

Foster KR, Ratnieks FLW (2000) Facultative worker policing in a wasp. Nature 407:692-693

Foster KR, Ratnieks FLW (2001a) Convergent evolution of worker policing by egg eating in the honeybee and common wasp. Proc R Soc Lond Ser B Biol Sci 268:169-174

Foster KR, Ratnieks FLW (2001b) The effect of sex-allocation biasing on the evolution of worker policing in hymenopteran societies. Am Nat 158:615-623

Foster KR, Ratnieks FLW (2001c) Paternity, reproduction and conflict in vespine wasps: a model system for testing kin selection predictions. Behav Ecol Sociobiol 50:1-8 
Foster KR, Ratnieks FLW, Gyllenstrand N, Thoren PA (2001) Colony kin structure and male production in Dolichovespula wasps. Mol Ecol 10:1003-1010

Foster KR, Gulliver J, Ratnieks FLW (2002) Worker policing in the European hornet Vespa crabro. Insectes Soc 49:41-44

Free JB, Weinberg I, Whiten A (1969) The egg-eating behaviour of Bombus lapidarius L. Behaviour 35:313-317

Gobin B, Billen J, Peeters C (1999) Policing behaviour towards virgin egg layers in a polygynous ponerine ant. Anim Behav 58:1117-1122

Greene A (1979) Behavioural characters as indicators of yellowjacket phylogeny (Hymenoptera: Vespidae). Ann Entomol Soc Am 72:614-619

Halling LA, Oldroyd BP, Wattanachaiyingcharoen W, Barron AB, Nanork P, Wongsiri S (2001) Worker policing in the bee Apis florea. Behav Ecol Sociobiol 49:509-513

Hammond RL, Keller L (2004) Conflict over male parentage in social insects. PLoS Biol 2:1-11

Hardin G (1968) The tragedy of the commons. Science 162:12431244

Hartmann A, Heinze J (2003) Lay eggs, live longer: division of labor and life span in a clonal ant species. Evolution 57:24242429

Hillesheim E, Koeniger N, Moritz RFA (1989) Colony performance in honeybees (Apis mellifera capensis Esch) depends on the proportion of subordinate and dominant workers. Behav Ecol Sociobiol 24:291-296

Hofer H (1998) The Hutterites: lives and images of a communal people. Hofer, Saskatoon, SK, Canada

Kikuta N, Tsuji K (1999) Queen and worker policing in the monogynous and monandrous ant, Diacamma sp. Behav Ecol Sociobiol 46:180-189

Landolt PJ, Akre RD, Greene A (1977) Effects of colony division on Vespula atropilosa (Sladen) (Hymenoptera: Vespidae). J Kansas Entomol Soc 50:135-147

Lee ET, Wang JW (2003) Statistical methods for survival data analysis, 3rd edn. Wiley, New York

Martin SJ, Beekman M, Wossler TC, Ratnieks FLW (2002) Parasitic Cape honeybee workers, Apis mellifera capensis, evade policing. Nature 415:163-165

Michener CD, Brothers DJ (1974) Were workers of eusocial Hymenoptera initially altruistic or oppressed? Proc Natl Acad Sci USA 71:671-674

Mock DW, Parker G (1998) The evolution of sibling rivalry. Oxford University Press, Oxford

Monnin T, Peeters C (1997) Cannibalism of subordinates' eggs in the monogynous queenless ant Dinoponera quadriceps. Naturwissenschaften 84:499-502

Moritz RFA, Hillesheim E (1985) Inheritance of dominance in honeybees (Apis mellifera capensis Esch). Behav Ecol Sociobiol 17:87-89

Nakata K, Tsuji K (1996) The effect of colony size on conflict over male-production between gamergate and dominant workers in the ponerine ant Diacamma sp. Ethol Ecol Evol 8:147-156

Pomeroy N (1979) Brood bionomics of Bombus ruderatus in New Zealand (Hymenoptera: Apidae). Can Entomol 111:865-874

Queller DC, Strassmann JE (1998) Kin selection and social insects. Bioscience 48:165-175

Ratnieks FLW (1988) Reproductive harmony via mutual policing by workers in eusocial Hymenoptera. Am Nat 132:217-236

Ratnieks FLW (1993) Egg-laying, egg-removal, and ovary development by workers in queenright honey-bee colonies. Behav Ecol Sociobiol 32:191-198
Ratnieks FLW (1995) Evidence for a queen-produced egg-marking pheromone and its use in worker policing in the honey-bee. J Apic Res 34:31-37

Ratnieks FLW (2000) Worker policing in the honey bee: basic facts and ideas. Insect Social Life 3:3-10

Ratnieks FLW, Reeve HK (1992) Conflict in single-queen hymenopteran societies - the structure of conflict and processes that reduce conflict in advanced eusocial species. J Theor Biol 158:33-65

Ratnieks FLW, Visscher PK (1989) Worker policing in the honeybee. Nature 342:796-797

Ratnieks FLW, Wenseleers T (2005) Policing insect societies. Science 307: 54-56

Ross KG (1985) Aspects of worker reproduction in 4 social wasp species (Insecta, Hymenoptera, Vespidae). J Zool 205:411-424

Saigo T, Tsuchida K (2004) Queen and worker policing in monogynous and monandrous colonies of a primitively eusocial wasp. Proc R Soc Lond Ser B Biol Sci [Suppl] 271:S509-S512

Siegel S, Castellan NJ (1988) Nonparametric statistics for the behavioral sciences, 2nd edn. McGraw-Hill, New York

Spradbery JP (1991) Evolution of queen number and queen control. In: Ross KG, Matthews RW (eds) The social biology of wasps. Cornell University Press, Comstock, Pa., pp 336-388

Starr CK (1984) Sperm competition, kinship, and sociality: a review of modern theory. In: Smith RL (ed) Sperm competition and the evolution of animal mating systems. Academic, Orlando, pp 427-464

Statsoft I (1995) STATISTICA for Windows (computer program manual). StatSoft, 2300 East 14th Street, Tulsa, Okla., http:// www.statsoft.com

Tóth E, Queller DC, Dollin A, Strassmann JE (2004) Conflict over male parentage in stingless bees. Insectes Soc 51:1-11

Tóth E, Strassmann JE, Nogueira-Neto P, Imperatriz-Fonseca VL, Queller DC (2002) Male production in stingless bees: variable outcomes of queen-worker conflict. Mol Ecol 11:2661-2667

Trivers RL, Hare H (1976) Haplodiploidy and the evolution of the social insects. Science 191:249-263

Visscher PK (1996) Reproductive conflict in honey bees: a stalemate of worker egg-laying and policing. Behav Ecol Sociobiol 39:237-244

Wenseleers T, Ratnieks FLW (2004) Tragedy of the commons in Melipona bees. Proc R Soc Lond Ser B Biol Sci [Suppl] 271:S310-S312

Wenseleers T, Ratnieks FLW, Billen J (2003) Caste fate conflict in swarm-founding social Hymenoptera: an inclusive fitness analysis. J Evol Biol 16:647-658

Wenseleers T, Hart AG, Ratnieks FLW (2004a) When resistance is useless: policing and the evolution of reproductive acquiescence in insect societies. Am Nat 164:E154-E167

Wenseleers T, Hart AG, Ratnieks FLW, Quezada-Euan JJG (2004b) Queen execution and caste conflict in the stingless bee Melipona beecheii. Ethology 110:725-736

Wenseleers T, Helanterä H, Hart AG, Ratnieks FLW (2004c) Worker reproduction and policing in insect societies. An ESS analysis. J Evol Biol 17:1035-1047

Wilson EO (1971) The insect societies. Harvard University Press, Cambridge, Mass

Winston ML (1987) The biology of the honey bee. Harvard University Press, Cambridge, Mass.

Woyciechowski M, Lomnicki A (1987) Multiple mating of queens and the sterillity of workers among eusocial Hymenoptera. J Theor Biol 128:317-327 